\title{
Influence of Green Organizational Response on Innovation Performance of Enterprises
}

\author{
Keting Lv \\ Guizhou University of Finance and Economics \\ Guiyang, China
}

\begin{abstract}
With the increasingly prominent environmental problems, there are some different opinions in academic circles on whether enterprises should carry out active environmental management. Based on the stakeholder theory, this paper discusses the impact of green organizational response on innovation performance of enterprises from the perspectives of shareholders, employees, consumers, government and suppliers. Finally, it is concluded that action of enterprises in positive green organizational response can promote innovation performance.
\end{abstract}

Keyword-green organizational response; innovation performance; stakeholder theory; enterprises

\section{INTRODUCTION}

In his report to the 19th national congress of the communist party of China (CPC), general secretary xi jinping pointed out that man and nature are a community of life. Since 2016, green development has become one of China's five major development concepts. The country has been stepping up environmental governance and addressing prominent environmental issues. On January 1, 2018, the environmental protection tax law of the People's Republic of China came into effect, making it the 18th tax in China and the first "green tax law". Although the country has raised the concept of green development to an unprecedented height, the main body of pollution prevention and control is enterprises, whose behavior determines the effectiveness of the environmental protection campaign.

It was not until 2007 that China's research on corporate social responsibility entered a period of rapid development and made some achievements. Only in recent years have scholars begun to pay attention to the relationship between enterprises' fulfillment of social responsibility and their innovation performance. Most scholars believe that enterprises' active fulfillment of social responsibility will have a positive impact on their innovation performance. For example, through the analysis of financial data of gem listed companies, some scholars found that the performance of social responsibility to shareholders of listed companies can improve the performance of innovation technology and innovation financial performance, while the performance of social responsibility to employees can improve the performance of innovation technology, but not necessarily translate into profits.

In his government report, premier li keqiang said that as the main body of pollution control, enterprises should have both external pressure and internal motivation. Enterprises with different property rights have different motivations for green organizational response behavior. The green organizational response behavior of state-owned enterprises is more influenced by political motivation, while non-state-owned enterprises only make positive green organizational response when it is "profitable". Therefore, this paper hopes to provide theoretical support for enterprises' green organizational response behaviors by studying the relationship between enterprises' green organizational response behaviors and their innovation performance.

\section{LITERATURE REVIEW}

\section{A. Green organizational response}

To achieve green development, enterprises' green organizational response behavior is the most important. Corporate green organizational response refers to the strategic layout of corporate environmental responsibility announcement, which reflects the process and degree of corporate environmental responsibility management. At present, researches on green organizational response are mainly classified according to the positive degree of environmental management.

Hunt (1990) took American enterprises as samples and divided them into five different environmental strategies according to their initiative in environmental management: initiator, fireman, corporate citizen, pragmatist, and activist. The initiator refers to the enterprise's refusal to fulfill its social responsibility and will not disclose the relevant information and treatment methods of the enterprise's environmental problems to the employees and the public. The difference between firefighters and initiator is only to make corresponding budget for possible environmental problems. Corporate citizens believe that enterprises should actively fulfill their environmental responsibilities and set up environmental management departments within the company. A pragmatist will actively participate in environmental management, but he only realizes the importance of environmental protection after paying a great price for environmental problems, while an activist will incorporate the fulfillment of environmental responsibility into the company's development strategy. Roome (1992) also made the same research in the UK. According to the attitude of enterprises towards environmental responsibility, he divided them into five types: non-performance, performance, performance plus, excellent business and environment and leadership advantages, from passive avoidance to active commitment. The two scholars used different names to classify the positive degree of environmental management of enterprises, but the descriptions of the five types were basically the same.

\section{B. Innovation performance}

Innovation plays a crucial role in the growth of enterprises and the development of society. Scholars' research and debate on innovation originated from schumpeter's discussion on the distinction between "innovation" and "invention". Up to now, there are many different views in academia. Amabile (1996) believed that innovation was the successful execution of creative ideas in the organization, or the successful application of new processes or products, provision of new methods and 
creation of new knowledge. Souder (1988) mainly emphasizes innovation as novel activities with great potential contribution to enterprise interests, while Rogers (1983) considers innovation as a major change of perception or practice. Innovation performance refers to the evaluation of the efficiency and effect of enterprise technology innovation activities, that is, the increase of enterprise value and business volume by the application of new technologies or new achievements.

From the perspective of enterprises, whether they should fulfill social responsibility has always been a controversial topic in the academic circle. Social responsibility for the implementation of the impact on innovation performance has not reached a consensus, also some scholars through the gem analysis found that the data of listed companies to shareholders of listed companies to fulfill social responsibility can improve the innovation technology performance and financial performance, and fulfill their social responsibility can improve technology innovation performance, but does not have to translate into profits (Chen guan, 2017).From the perspective of knowledge stakeholder integration, fulfilling social responsibility will have an inverted u-shaped impact on enterprise innovation performance. The higher the uncertainty of the market, the better the role of fulfilling social responsibilities in promoting technological innovation performance (li wenxi, 2018).

From the perspective of external environment, the government's incentive effect on the industry is limited. Research on equipment manufacturing industry in the beijing-tianjin-hebei region finds that industrial policies and tax incentives can inhibit enterprise technological innovation (yu shujiang, 2019). Currently, the efficiency of regional innovation in China is low, which is due to the high efficiency of regional innovation research and development with balanced economic development and the high conversion rate of research and development results in regions with unbalanced economic development. Relevant policies of innovation in China pay more attention to the transformation of research and development results rather than research and development (wang dong, 2019).Some scholars also found that enterprises' $r$ \& d activities were not carried out independently, and cooperative $\mathrm{r} \& \mathrm{~d}$ activities and learning behaviors between groups could significantly improve enterprise innovation performance (wu aihua, 2015).Meanwhile, external knowledge search is an important way for enterprises to obtain competitive advantages. Both the depth of knowledge search and the width of knowledge search can effectively improve the innovation performance of enterprises, while maintaining the balance between the width of knowledge search and the depth of knowledge search can reduce the risk of innovation and research and development (su daoming, 2017).

\section{Stakeholder theory}

Freeman first put forward the term "stakeholder" in his book strategic management: an analytical approach to stakeholder management published in 1984.Freeman believes that the development of any company is inseparable from the input or participation of all stakeholders, and enterprises pursue the overall interests of stakeholders, not just the interests of some subjects. According to clarkson, "stakeholders and enterprises have invested some physical capital, human capital, financial capital or something valuable in the enterprise, and thus have taken some forms of risk; Or they take risks because of corporate activity." Clarkson's definition introduces the concept of specific investment and makes the definition of stakeholder more specific[1]

Freeman (1984) believes that stakeholders have different influences on enterprises due to different resources. He divided stakeholders into three aspects :(1) those who hold shares of the company, such as board members and managers, are called ownership stakeholders;(2) the relevant groups that have economic contact with the company, such as employees, creditors, internal service institutions, employees, consumers, suppliers, competitors, local communities and management structure, are called economic dependent stakeholders;(3) stakeholders related to the company's social interests, such as government agencies, media and special groups, are called social stakeholders.

\section{THE IMPACT OF GREEN ORGANIZATIONAL RESPONSE ON INNOVATION PERFORMANCE}

According to stakeholder theory, corporate goals are not only accountable to shareholders, but also to employees, consumers, governments, creditors, suppliers and other stakeholders. The interests pursued by enterprises are the overall interests of stakeholders, not just the interests of shareholders. The development of any enterprise is inseparable from the input or participation of all stakeholders, stakeholders rely on the enterprise to achieve personal goals, and enterprises also need them to maintain the survival and development of the enterprise[2]. According to this paper, green responsive behaviors of enterprises mainly include stakeholders from shareholders, employees, consumers, government and suppliers Therefore, the influence of green organizational response on enterprise innovation performance is discussed from these five aspects.

\section{A. Shareholders}

The innovation and research activities of enterprises need a large amount of capital investment, and the support of shareholders is the guarantee of adequate capital. Mr. Li weian believes that introducing the concept of "green management" is an inevitable choice for enterprises to achieve sustainable management in the "post-crisis" era. The sooner an enterprise realizes "green management", the better it will grasp the initiative of future competition. Green responsive behavior of enterprises can help enterprises to establish sustainable competitive advantages and obtain greater benefits for shareholders[3].Therefore, shareholders are more willing to bring environmental management into the scope of enterprise strategy, so as to achieve long-term development of the enterprise. Shareholders can provide funds for enterprises' environmental management, increase enterprises' investment in green research and development, and improve innovation output.

\section{B. Employees}

By actively fulfilling social responsibilities, enterprises can gain the recognition of employees, stimulate their enthusiasm for work, increase their work input, and improve the productivity of innovation. In one experiment-based study, corporate social responsibility information in the recruitment market provided sufficient human capital for corporate innovation activities by generating expected pride and attractiveness to job seekers. However, job seekers' recognition of corporate social responsibility is affected by corporate scale, and smaller enterprises are easily regarded as instrumentalist 
motives[4].The implementation of the enterprise's environmental protection strategy can increase the organizational identity of the enterprise's employees, make more effective cooperation between employees and innovate product concepts, further expand the enterprise's green innovation ability and improve the innovation performance of the enterprise.

\section{Consumers}

As a way to fulfill social responsibility, enterprises' green organizational response behavior can help enterprises establish a "responsible" pro-social image, gain the recognition of consumers, and cultivate a large number of loyal customers. However, corporate social responsibility may also lead to "thankless" consequences[5]. If consumers believe that corporate social responsibility is motivated by self-interest, the effect of corporate social responsibility will be greatly reduced. Taking the initiative to take social responsibility is more likely to be recognized by consumers. If consumers think that enterprises are forced to do good deeds, it will cause negative perception of consumers. Well-known enterprises are more likely to be supervised by local residents, and their responsible behaviors can stimulate consumers' willingness to spread positive word-of-mouth. Consumer recognition can improve the performance of enterprises, help enterprises to develop the market, and establish a sustainable competitive advantage[6].On the one hand, the improvement of enterprise performance can ensure the investment of sufficient funds in r\&d activities and increase the innovation output; On the other hand, new products of enterprises are more easily accepted by consumers after entering the market, thus improving the success rate of innovation.

\section{Government}

Enterprises of different nature have different motivations for green organizational response. The environmental management of state-owned enterprises is more politically motivated than that of non-state-owned enterprises, which only conduct environmental management when it is "profitable"[7].With the increasingly serious environmental problems, the government's supervision of environmental pollution is becoming more and more strict, and the enterprises that violate relevant laws should be rectified within a time limit. Enterprises can reduce or avoid the impact of the change of legal environment on their daily business activities and save a lot of legal fees by adopting positive green organizational response behavior. Enterprises' green organizational response behavior can help enterprises gain political legitimacy, easier to obtain government tax incentives and environmental protection subsidies, so as to support enterprises' innovation activities and improve innovation performance.

\section{E. Supplier}

Green responsive behavior can enable enterprises to gain recognition from suppliers, strengthen communication and cooperation with stakeholders, and establish long-term partnership rather than simple vendor-customer relationship[8].The knowledge base of an enterprise is the source of innovation. Communication and cooperation with stakeholders can renew the knowledge reserve of an enterprise and promote its innovation performance. Environmental management of enterprises will be concerned by environmental interest groups, market forces and stakeholders. The development of pollution prevention and control projects is conducive to gaining the sense of identity of stakeholders and obtaining creative sources from the outside. Enterprises with poor environmental performance will increase the competition risk of supply chain partners. Enterprises can require supply chain partners to follow unified environmental management requirements and establish long-term partnership, which is conducive to information exchange and knowledge transfer between supply chain partners and promotes product research and development and process innovation.

\section{CONCLUSION}

This paper discusses the impact of green organizational response on enterprise innovation performance from five aspects of stakeholders: shareholders, employees, consumers, government and suppliers. The results show that shareholders, employees, consumers, governments and suppliers all have a positive impact on the innovation performance of enterprises. Shareholders hope that the company can build a sustainable competitive advantage and seek greater development, so they can provide financial security and increase research and development investment. Enterprise "responsible" pro-social image can obtain the identity of the society, for the innovation of the enterprise research and development activities to recruit excellent talents, new products on the market is more easily accepted by consumers, improve the success rate of innovation, the government will provide enterprises with tax breaks and subsidies, security firms are not produced in the process of research and development funds shortage problem. Green organizational response can help enterprises establish long-term partnership with external stakeholders, better embed enterprises into the external relationship network, and help enterprises obtain a large number of sources of knowledge, technology and creativity from the outside world, so as to improve innovation output. Therefore, enterprises' positive green organizational response can have a positive impact on innovation performance from the five aspects of shareholders, employees, consumers, government and suppliers.

\section{REFERENCES}

[1] Freeman, Edward R . Strategic Management (A Stakeholder Approach) \|P Preface[J]. 2010

[2] Chen Y, Tang G, Jin J, et al. Linking market orientation and environmental performance: The influence of environmental strategy, employee's environmental involvement, and environmental product quality[J]. Journal of Business Ethics, 2015.

[3] Rappaport A, Flaherty M F. Corporate Responses to Environmenta Challenges: Initiatives by Multinational Management[M]. New York: Quorum Books, 1992

[4] Teeter P, Sandberg, Jörgen. Constraining or Enabling Green Capability Development? How Policy Uncertainty Affects Organizational Responses to Flexible Environmental Regulations[J]. British Journal of Management, 2017.

[5] Wang C , Hu Q . Knowledge sharing in supply chain networks: Effects of collaborative innovation activities and capability on innovation performance[J]. Technovation, 2017.

[6] Thomas Clauß. Measuring Business Model Innovation: Conceptualization, Scale Development and Proof of Performance[J]. R\& D Management, 2017.

[7] Soto-Acosta P, Popa S, Daniel Palacios-Marqués. Social web knowledge sharing and innovation performance in knowledge-intensive manufacturing SMEs[J]. The Journal of Technology Transfer, 2016.

[8] Shah A . Business Model Innovation and SMEs Performance - Does Competitive Advantage Mediate?[J]. International Journal of Innovation Management, 2018. 